\title{
On Translation Varieties of English Movie Titles-Language Features in Chinese Mainland, Hong Kong, and Taiwan
}

\author{
Xiaoxuan $\mathrm{Du}^{1, \mathrm{a}}$ \\ ${ }^{1}$ School of Foreign Languages, Dalian Neusoft University of Information, Dalian, Liaoning, China \\ aduxiaoxuan@neusoft.edu.cn
}

\begin{abstract}
The author concentrates on translation varieties of English movie titles in Chinese Mainland, Hong Kong and Taiwan by consulting large numbers of references. The author compares and studies the differences of translation standard, emphasis and principles in these three areas by analyzing some examples, in the hope of finding more appropriate method of translating English movie titles.
\end{abstract}

Keywords: movie translation, translation comparison, translation standard

\section{INTRODUCTION}

As the effect of globalization, especially the ever-growing cultural globalization, more and more foreign cultures are being introduced into our country continuously. Movies are one of them, which are in urgent need of being translated into Chinese for Chinese audience. The title is the soul of a movie, thus translation of movie titles is quite important. It decides whether a foreign movie can be accepted by Chinese audience and popularized in China. A splendid translation of a foreign movie title can be passed down generation after generation with the movie, while an unsuccessful translation version may cover up an excellent movie. Each language has its own rules. When doing translation work, we must accurately convey the original text according to the characteristics of each language. We should not blindly follow the original text, but also retain the original flavor. Translators have been facing this dilemma. [1]

However, because of dissimilar cultural backgrounds, for instance, economic and social systems, as well as living habits, different translation versions of the same movie title are found in Chinese Mainland, Hong Kong and Taiwan. The author will mainly concentrate on translation of English movie titles. By comparing these different translation versions, as well as analyzing their advantages and disadvantages, the author tend to explore the better way to translate English movie titles.

\section{GENERAL INTRODUCTION ENGLISH MOVIES}

\subsection{History of English Movies}

English movies mainly come from two parts of the world, namely Europe and America. These two areas have always been playing an indelible role in the world's movie industry. How did movies develop and what is the current situation of movies in these two areas?

On December $28^{\text {th }}, 1895$, thanks to the efforts of Lumiere brothers in France, short videos were released to the public, which symbolized the birth of movie. At first, those videos were silent and contained only scenes or segments of dramas. Gradually, those videos became an independent artistic form. Sound movies came into being in the 1920s and movies developed into a comprehensive art. Later on, color movies, three-Ds came into daily life. In Europe, movies became a cultural phenomenon and modern art which were of great influence in the 1950s. It concerned with almost every fields of natural science and human science.

In the history of European movies, there are quite a lot of classics. Especially since the 1980s, many European movies have won universal praise, such as The French Lieutenant's Woman (1981), Cinema Paradiso (1989), Leon (1995), Lock, Stock and Two Smoking Barrels (1999), Le Fabuleux Destin d'Amelie Poulain (2001), The Pianist (2002), etc. Many Chinese audience are greatly impressed by these movies.

In 1893, "Black Maria" studio was established by T. A. Edison and it is considered to symbolize the beginning of the history of American movies. American movies were popularized in 1896. Because of the strict censorship system, the main accomplishment of American silent movies at that time generally were three forms - comedies, western films and historical films. In the mid-1920s, luxurious cinemas took place of nickel theatres. What's more, in order to win over commercial radio broadcasting, Hollywood movie companies improved their stereo system and produced sound movies at the end of the 1920 s,

On October $6^{\text {th }}, 1927$, the world's first sound feature movie - Jazz singer, came into being. And on July $6^{\text {th }}$, 1928 , Lights of New York, made by Warner Bros., symbolized that sound movies were released publicly. All the movies were sound ones by the 1930s, except for a few silent ones acted by Charles Chaplin.

After a period which is called the "Golden Age" of American movies, almost every big movie company began to disintegrate or shift to other fields. Afterwards, led by S. Spielberg's Jaws (1975) and Lucas's Star Wars (1977), American movies recovered. After that, American movies developed rapidly again.

Nowadays, American movies are enjoying the world's movie market dominance. When talking about American movies, the first thing that comes into the audience's mind is Hollywood, which is located in the northwest of Los Angeles, California. Hollywood movies are a way to introduce 
American culture to the world.

\subsection{Classification of Movies}

Movies can be classified into many types. Different types of movies can be translated in different ways. According to this rule, it is sensible to learn how movies are actually classified, so that the practice of translating may have a much clearer guidance, and the audience will have a better understanding of the movies they are watching.

Traditionally, movies are classified according to their subject matters and the techniques adapted when making them. They can roughly be classified into feature films and non-feature films. Feature films can continually be classified into westerns, gangster films, musicals, comedies, thrillers, sci-fi films, disaster films, war films, sports films; and non-feature films include selected films, news clips, documentary films, scientific films and landscape films.

This is only one of the many ways to classify movies. There are still a lot of other methods. For example, movies can be divided into silent movies and sound ones, and they can also be categorized into black-and-white movies and color ones.

\section{TRANSLATION VARIETIES OF ENGLISH MOVIE TITLES IN CHINESE MAINLAND, HONG KONG AND TAIWAN}

There are three basic principles in translating English movie titles, namely, information equivalence, culture equivalence and aesthetics equivalence. Though there is a translation standard which is widely accepted in the translation circle, great differences still exist in translation versions in these three areas.

Table 1 Some Examples of Translation Similarities in Chinese Mainland, Hong Kong and Taiwan

\begin{tabular}{|l|l|l|l|}
\hline English movie title & $\begin{array}{l}\text { Translation version in } \\
\text { Chinese Mainland }\end{array}$ & $\begin{array}{l}\text { Translation version in } \\
\text { Hong Kong }\end{array}$ & $\begin{array}{l}\text { Translation version in } \\
\text { Taiwan }\end{array}$ \\
\hline $\begin{array}{l}\text { All Quiet on the Western Front } \\
(1930)\end{array}$ & 西线无战事 & 西线无战事 & 西线无战事 \\
\hline The Godfather (1972) & 教父 & 教父 & 教父 \\
\hline Apocalypse Now (1980) & 现代启示录 & 现代启示录 & 现代启示录 \\
\hline Dances with Wolves (1990) & 与狼共舞 & 与狼共舞 & 与狼共舞 \\
\hline
\end{tabular}

Table 2 Some Examples of Translation Varieties in Chinese Mainland, Hong Kong and Taiwan

\begin{tabular}{|c|c|c|c|}
\hline English movie title & $\begin{array}{l}\text { Translation version in } \\
\text { Chinese Mainland }\end{array}$ & $\begin{array}{l}\text { Translation version in } \\
\text { Hong Kong }\end{array}$ & $\begin{array}{l}\text { Translation version in } \\
\text { Taiwan }\end{array}$ \\
\hline Ben-Hur (1959) & 宾虚 & 宾墟 & 宾汉 \\
\hline West Side Story (1961) & 西区故事 & 梦断城西 & 西城故事 \\
\hline $\begin{array}{l}\text { Guess Who's Coming to Dinner } \\
\text { (1967) }\end{array}$ & 猜一猜谁来吃晚餐 & 谁来付宴君且猜 & 谁来晚餐 \\
\hline Raging Bull (1980) & 愤怒的公牛 & 狂牛 & 蛮牛 \\
\hline The Deer Hunter (1981) & 猎鹿人 & 猎鹿者 & 越战猎鹿人 \\
\hline The Terminator (1985) & 终结者 & 未来战士 & 魔鬼终结者 \\
\hline Fatal Attraction (1987) & 致命的诱惑 & 擘恋 & 致命的吸引力 \\
\hline$J F K(1992)$ & 肯尼迪 & 惊天大刺杀 & 谁杀了甘乃迪 \\
\hline Schindler's List (1994) & 辛德勒的名单 & 舒特拉的名单 & 辛德勒的名单 \\
\hline Courage Under Fire (1996) & 生死豪情 & 生死豪情 & 火线勇气 \\
\hline Daylight (1996) & 十万火急 & 龙出生天 & 十万火急 \\
\hline Jumanji (1996) & 勇敢者的游戏 & 逃出魔幻纪 & 野蛮游戏 \\
\hline Titanic (1997) & 泰坦尼克号 & 铁达尼号 & 铁达尼号 \\
\hline Saving Private Ryan (1998) & 拯救大兵瑞恩 & 雷霆救兵 & 抢救雷恩大兵 \\
\hline American Beauty (1999) & 美国丽人 & 美丽有罪 & 美国心玫瑰情 \\
\hline Along Came a Spider (2001) & 蛛丝马迹 & 血网追凶 & 全面追缉令 \\
\hline Captain Corelli’s Mandolin (2001) & 曼佗林之恋 & 火线有情天 & 战地情人 \\
\hline The Interpreter (2005) & 翻译风波 & 叛译者 & 双面翻译 \\
\hline
\end{tabular}

Compared with translators in Hong Kong and Taiwan, translators in Chinese Mainland put more emphasis on the aesthetics principle. Firstly, the words that the translators in Chinese Mainland choose are usually quite formal. For example, Captain Corellis Mandolin is translated into 火线
有情天 in Hong Kong, and 战地情人 in Taiwan. In Chinese Mainland, the movie title is translated into 曼佗林之恋, which sounds more elegant. Secondly, translators in Chinese Mainland are likely to use four-character expressions, which seem more refined and rhythmical, such as The Interpreter is 
translated into 叛译者 in Hong Kong, but 翻译风波 in Chinese Mainland. Thirdly, it is more rarefied for translators in Chinese Mainland to use idioms to translate English movie titles. For example, Along Came a Spider is translated into 血网追凶 in Hong Kong, 全面追缉令 in Taiwan, but 蛛 丝马迹 in Chinese Mainland.

Talking about translation strategy, literal translation is generally used in Chinese Mainland in order to show the original conception. For instance, Original Sin is literally translated into 原罪 here. For some abstract English movie titles, they frequently combine literal and free translation methods together. For example, The Phone Booth is translated into 狙击电话亭, and Peter Pan is translated into 小飞侠彼得潘, etc. Only when an English movie title is too abstract for audience to understand would translators in Chinese Mainland adopt complete free translation, such as The Bourne Identity is translated into 谍影重重.

Generally speaking, translation versions in Chinese Mainland are traditional and conservative. The advantages of this kind of translation lie in that it can reserve the mysteries of these English movies, and the simple and graceful expressions it adopts are artistic. At the same time, its disadvantages cannot be ignored. Sometimes, it is rigid, lacks flexibility and attraction.

It is worth noticing that translation of English movie titles in Hong Kong and Taiwan is not limited to free translation. Translators there value literal translation as well. For some abstract English movie titles, they also combine literal and free translation methods together. The greatest obstruction for them is the lack of innovation spirit.

According to what have been mentioned above, there are great differences in translation standard and strategy in translating English movie titles in Chinese Mainland, Hong Kong and Taiwan. The author has concluded two reasons:

Firstly, social system is not exactly the same in these three areas. Chinese Mainland is, to some extent, traditional. Some limitations that have been set to restrict the movie industry are stricter. Due to historical reasons of Hong Kong and Taiwan, translation versions there are comparatively various and lively.

Secondly, historical and cultural backgrounds are slightly different in these three areas. Translation is the exchange between two different cultures. Therefore, when dealing with the two different cultures in China and English-speaking countries, the translation of film titles makes cultural infiltration phenomena happen frequently. [2] Translating is very difficult, especially when it comes to cultural information and detailed description. [3] Hong Kong is an intersection of Chinese and western cultures. Translation style there sometimes possesses characteristics of both sides. Though the system in Taiwan is similar to that in Hong Kong, foreign influence is not so strong in Taiwan. Chinese traditional thought is still deep-rooted there. Therefore, some translation versions are much the same with those of Chinese Mainland. The translation versions are influenced by the context to a large extent. Context does not refer to the external environment, be it the text preceding or following an utterance, situational circumstances, cultural factors. [4]

\section{CONCLUSION}

Excellent translations of English movie titles should be both accordant with the original titles and in line with the themes. Moreover, good translations are both artistic and commercialized. Translation of English movie titles has to be accepted by most of the audience. Therefore, translators should put the potential audience into consideration. Similarities and varieties coexist in translation versions of English movie titles in Chinese Mainland, Hong Kong and Taiwan. These differences are mostly caused by dissimilar social systems, culture backgrounds and language habits. What's more, these differences lead to great trouble for people in Chinese Mainland, Hong Kong and Taiwan to communicate. It is not sensible to decide which method of translation is better. Generally speaking, each translation version of English movie titles in these three areas is accepted by local people. It can be seen that only when our country are completely unified and Chinese, or Putonghua is truly widespread all over China, can translation versions of English movie titles in Chinese Mainland, Hong Kong and Taiwan be identical. During this period, translators in these three areas should learn from each other to make contributions to the movie translation circle in China.

\section{REFERENCES}

[1] Du,Xiaoxuan.On Application of Theme-Rheme Theory in English-Chinese Legal Contract Discourse Translation[A].Proceedings of the 2nd Symposium on Health and Education 2019 (SOHE 2019)[C].Wuhan:Atlantis Press,2019:488-492.

[2] Mao,Hehua.Literal Translation or Free Translation--Study on Translation Strategies of English Movie Titles[J].Journal of Shazhou Professional Institute of Technology,2012(03):53-56.

[3] Du,Xiaoxuan.On Translation of Personalized Language Style of Grannie Liu and Lady Dowager in "Dream of Red Mansions"[J].Chinese and Foreign Communication,2019,26(20):56-57.

[4] Gutt,Emst-August.Translation and Relevance:Cognition and Context[M].Shanghai:Shanghai Foreign Language Education Press,2004:27. 